\title{
Study on the Decline of the British Aristocracy from the Perspective of Modernization
}

\author{
Jia Liu ${ }^{1,2, a}$ \\ ${ }^{1}$ School of History and Culture, Sichuan University, Chengdu, 610065 \\ ${ }^{2}$ College of History, Geography and Tourism, Chengdu Normal University, Chengdu, 611130 \\ a email: liujialiujia68@163.com
}

Keywords: British aristocracy; decline; modernization

\begin{abstract}
The British aristocracy has a long history and its strong toughness and continuity are remarkable. It could survive and develop through its own adjustment and variability. However, in the face of the impact of modernization, it formed irreconcilable contradictions with modernizations such as economic industrialization, political democratization, and social welfare and so on. Eventually, the British aristocracy fell into irreparable decline. The gradual feature of this decline was consistent with the model of modern British development.
\end{abstract}

\section{Introduction}

The British aristocratic system has a long history. It began in the Anglo-Saxon period, established in the Norman period, experienced the rise and fall of the vicissitudes, and ushered in the prosperous period after the Glorious Revolution, as the historian called the "aristocratic era" [1], and fell into irreparable decline in the early twentieth Century. In the course of the millennium, its toughness and continuity were amazing. After several ups and downs, it could always adapt to the development of society and regain its vitality through its own adjustment and variation. However, why did the British aristocracy fail to survive in twentieth Century?

The Industrial Revolution opened the course of British modernization and profoundly changed all aspects of British society. Generally speaking, "modernization refers to the profound changes in the human society since the eighteenth Century Industrial Revolution. It includes the historical process and change from traditional economy to modern economy, traditional politics to modern politics, traditional society to modern society, traditional civilization to modern civilization”. [2] In fact, whenever confronted with challenges, the British aristocracy made adjustments to survive for a thousand years. However, in the face of the modernization, the modernity required by modernization, such as economic industrialization, political democratization, social urbanization, and welfare, made every initiative or passive change of the British aristocracy in the direction of collapse. Eventually the British aristocracy fell into irretrievable decline. This profound social change, in Britain, was a "quiet revolution" and reflected a kind of lag, which was in line with conservatism and gradualism in the modern British development model.

\section{Conflict with Economic Modernization}

"Economic modernization refers to the process of economic development and economic restructuring with technology as the forerunner and industrialization as the core.... that is, the transition from agricultural economy to industrial economy." [3] In this process, the proportion of agriculture in the national economy is declining, and its dominant position is gradually replaced by industry. In the United Kingdom, "from 1867 to 1874, agriculture accounted for $15.7 \%$ of the net national income, and then declined year by year. By 1925-1934, it only accounted for 3.9\%.” [4] Correspondingly, the overall economic strength of the stratum that relied on agricultural production also declined.

The British aristocracy was such a group that was inseparable from the land, just as the 14th 
generation Derby Count said in the House of Lords in 1846, the so-called nobles were "a great landowner in this country." [5] The economic foundation of the British aristocracy was the ownership of large land. Specifically, the aristocracy depended on the possession of a large number of land to become the owner of social wealth, and then held political privileges and occupied advantages in all aspects of society. [6] Before the Industrial Revolution, Britain was still an agricultural society as a whole, and the nobility had an absolute economic advantage. However, after the Industrial Revolution, Britain started the process of modernization, and the proportion of agriculture in the national economy was declining, and the economic superiority of the land aristocracy was also losing.

In fact, "In the history of Britain, the aristocracy as a whole had never stood on the opposite side of history. It always kept up with the development of the trend, even if it was forced to do so." [5] For example, when the commodity economy infiltrated into the countryside earlier in the 15th and 16th centuries, the nostalgic new aristocrats changed their business model and engaged in agricultural production with capitalism in the Enclosure. After the Glorious Revolution, the British new aristocracy used political advantages to push the capitalist land ownership to its peak, and its economic advantage reached its peak. After the Industrial Revolution, in the face of economic modernization, some land aristocrats did not stick to stereotypes, but actively involved in new areas. But since they were the holders of large quantities of land, their investments were mostly confined to mining and transportation industries which were directly related to real estate. While in the following Second Industrial Revolution, new industries flourished such as electricity, chemicals, and automobile manufacturing and so on, but the British aristocracy was less involved. If in the pre-industrial society, the British aristocracy could still be able to maintain economic advantages through changing the mode of land management; while, with the deepening of economic modernization, the British aristocrats were unable to rely on the ownership of land resources and the fine adjustment of business models to compete with industrial capitalists who invested in modern emerging fields. "Between 1809 and 1879, 88\% of Britain's millionaires were aristocratic landlords, but it dropped to 33\% from 1880 to 1914." [7] The decline in the economic strength of the aristocratic landlords made them lose the qualification and ability to continue to hold a large amount of land, and part of them sold their land, which even led to a decline in land prices. [8]

At the same time, in the industrial society, the new rising social elite was no longer the landlord who had made fortune by land. "Among the new lords in House of Lords from 1901 to 1957, there were 91 aristocrats whose occupation and family background were related to industry, accounting for $16.2 \%$; the law, 91 , accounting for $16.2 \%$; real estate, 46 , accounting for $8.3 \%$; management, 42 , accounting for $7.6 \%$; finance, 27 , accounting for $4.9 \%$; newspapers, 12 , accounting for $2.2 \%$; business, 12, accounting for 2.2\%; others, 235, accounting for 42.3\%." [9] The "other" here mainly referred to the middle class, most of whom were freelancers and social activists. It could be seen that landowners only occupied a small share, which was consistent with the decline in the proportion of agriculture in economic modernization. If in the pre-industrial society, adjusting the British aristocratic composition could save its decline, once breaking through the traditional society and coming into the modern society, every change of the British aristocracy was constantly disintegrating itself. "It had evolved from a landlord class to a mixture of old land aristocrats and bourgeois chaebol, middle class representatives and a minority of civilian representatives.” [10] The change in the composition had weakened the connotation of British aristocracy in terms of class structure and removed the essence of the British aristocracy in the economic position.

\section{Conflict with Political Modernization}

Generally speaking, political modernization refers to the transformation from traditional politics to modern politics, that is, the process of abandoning the autocratic system and establishing a new democratic political order. Among them, political democratization and legalization are important signs of political modernization. Looking at the political modernization of European countries, there is a regular and sequential development vein, that is, from the rule of monarch to aristocracy and to the form of "public". 
The development of British regime also followed this path. In 1688, the "Glorious Revolution" overthrew the autocratic monarchy, gradually established the constitutional monarchy, and established the principle of "the supremacy of the parliament", which laid the basic trend of political democratization in Britain. Since then, the United Kingdom had undergone democratized reforms within the framework of the parliament. In general, the British Parliament consisted of three parts: King, House of Lords and House of Commons. At first, the king still played a more important role. Subsequently, the political vacuum caused by the decline of the royal power was filled by the rule of the aristocratic oligarchy. The aristocratic oligarchy had long been entrenched in House of Lords and enjoyed extensive powers to control House of Commons and master the state power. The most striking feature of the house of Lords was its non-representativeness, which meant its members were neither elected either directly or indirectly, nor by the principle of regional representation, but by hereditary and King's will. Such personnel arrangements were obviously contrary to the requirements of democratization of modern politics, and their legitimacy had been questioned. "House of Lords was an inopportune institution. It was a social natural body based on privileges and wealth, which violated modern democracy and should be abolished". [11] At the same time, with the development of the modern British economy, the growing bourgeoisie also demanded political power to match the economic strength. As a result, House of Commons gradually became the core of the British Parliament, from the "supremacy of parliament" to the "supremacy of the House of Commons". Democracy then expanded beyond the aristocracy, and the political superiority of the British aristocracy no longer existed.

Specifically, in the middle of nineteenth Century, the three parliamentary reforms in Britain finally realized the universal suffrage for adult men. The Parliament Act, formulated by the Liberal Party and the Labor Party in 1911 and 1949, made House of Lords of the aristocracy unauthorized to veto the bill passed by House of Commons, and the legislative power of the aristocracy was weakened. The Life Peerages Act 1958 stipulated that the hereditary aristocracy would no longer be established and the hereditary nature of the house of Lords would be shaken. The Aristocratic Act 1963 stipulated that nobles had no right to become members of the House of Commons and prime ministers, unless he gave up the title of nobility and participated in House of Commons election as a civilian. The reforms of civil service system from 1850s to 1870s stipulated that most civil servants should be appointed by examinations, which deprived of the political privileges of the land aristocrats in the administrative field. In 1999, the House of Lords Act 1999 proposed by the Labor government abolished the hereditary nobility's ability to inherit parliamentary members and advocated that members of parliament should be elected by the public. In this way, the privilege of the hereditary nobility in House of Lords that lasted for more than 600 years was abolished. [12] The British aristocracy system had also gradually declined in the political modernization trend in which democracy triumphed over autocracy and equality prevailed over privileges.

\section{Conflict with Social Modernization}

Social modernization refers to a revolutionary social change in the social field. The social progress and development, including the lifestyle, quality of life, national culture, health quality, social concept, social welfare, social justice, etc., are caused by the transformation from agricultural society to industrial society and from traditional society to modern society. The China Modernization Report 2006 summarizes social modernization into six basic connotations, three major areas and 12 sub-fields. [13] Among them, social welfare and social equity are important indicators of social modernization.

The British aristocracy's long-term monopoly of political and economic privileges was obviously against social equity, thus arousing the resentment of social progressives. Early in the early nineteenth Century, David Ricardo, an economist, revealed the parasitism of the land aristocracy, and the utilitarian thinker, John Stuart Mill, was dissatisfied with the land aristocracy who exploited the other members of the society. In 1861, John Bryce and others published a controversial statement, pointing out that the land of the whole United Kingdom was occupied by 30,000 people, and less than 150 of them occupied half of the land, and the concentration of land was almost 
beyond all European countries. In addition, the peasant class could not stand the exploitation of rent, and the struggles against rent were accompanied by agricultural crises at the end of the 19th century. All these forced the government to carry out reforms and move towards social equity. In 1894, the Liberal Party Cabinet began to collect estate taxes. Although the tax rate only accounted for 8\% of the total property of households with more than 1 million pounds, it was increasing year by year, reaching $60 \%$ in 1939. [1] Not only that, during the First World War, the government began to impose progressive income tax, and the tax amount also was rising.

In political modernization, the British bipartisan politics had gradually matured. In order to be in power, the Labour Party and the Liberal Party must be supported by the voters and the majority of the parliament, so they did not dare to violate the social modernization trend of building the welfare state after World War II. The Labour Party represented the middle class that grew up in the modern economy. These socialists were ambitious. Before Clement Richard Attlee came to power, they put forward loud slogans- food, work and housing, and promised to achieve a relatively sound social security system. And how to raise such a large sum of money needed to build a welfare society? The wealth of aristocratic landlords bore the brunt. The Labour Party had no mercy on the deprivation of the wealth of the landlords and nobles. Even when the Conservative Party came to power in 1951, it did not dare to fundamentally change the tax policy which was called "killing the rich and helping the poor" by the aristocracy. Since then, the British two parties had taken turns in power, and the nobility landlords were all hopeless. As a result, the wealth of the aristocratic landlord was deprived by the way of paying inheritance tax and progressive income tax in the construction of welfare state and gradually realizing social justice.

\section{Conclusion}

Throughout the development of the British aristocracy, it was founded in the age of feudal serfdom, based on the possession of real estate, and marked by the hereditary rank of political status. [14] As a result, it developed in a feudal society with agriculture as its main economic component and flourished in the early stages of modern society with feudal remnants. In the transition to the modern society, the industrialization of modern economy disintegrated the economic superiority of the British aristocracy. The democratization of modern politics swallowed the legitimacy of the British aristocratic hereditary privilege. The welfare and equity of the modern society made the British aristocracy's economic and political advantages unsustainable, and the decline of the British aristocratic system was inevitable. The welfare and fairness of modern society made the British aristocratic economy the political advantage is unsustainable, and the decline of the British aristocracy was inevitable. However, such a profound social change: the collapse of an economic system-large land ownership, and the decline of a privileged class-the British aristocracy, was accomplished through peaceful evolution and bloodless legislation. This embodied the British tradition of compromise between the British opposing classes and the gradual conservative development pattern of Britain. This model provided a path for the world in transition to deal with the conflict between tradition and modernity.

\section{References}

[1] Yan Z. X. History of British Aristocrats. Beijing: People's Publishing House, 2000.

[2] China Modernization Strategy Research Group, China Center for Modernization Research. China Modernization Report 2004. Beijing: Peking University Press, 2004.

[3] Wei Z.H. Theory and Practice of China's Modernization. Chengdu: Sichuan University Press, 2008.

[4] Deane P., Cole W.A. British Economic Growth 1688-1959. Cambridge: University Press, 1962.

[5] Qian C.D., Chen X.L. The Origin of British Cultural Model. Shanghai: Shanghai Academy of Social Sciences Press, 2003. 
[6] Allen D.W. A theory of the pre-modern British aristocracy. Explorations in Economic History, 2009, 46(3):299-313.

[7] Rubinstein W. D. Men of Property: The Very Wealthy in Britain since the Industrial Revolution. London: Croom Helm, 1981.

[8] Rubinstein W. D. Elites and the Wealthy in Modern British History: Essays in Social and Economic History. Brighton: Harvester u.a, 1987.

[9] Guttsman W.L. The British Political Elite. New York: Basic Books, 1963.

[10] Yan Z.X. Research on the British Aristocratic System. Beijing: People's Publishing House, 2006.

[11] David C. Decline and Fall of the British Aristocracy. New Haven, Conn.: Yale University Press, 1990.

[12] Dingle L, Miller B. A summary of recent constitutional reform in the United Kingdom. International Journal of Legal Information, 2005, 33(1):71-102.

[13] China Modernization Strategy Research Group, China Center for Modernization Research. China Modernization Report 2006. Beijing: Peking University Press, 2006.

[14] Crouch D. The English Aristocracy, 1070-1272. New Haven, Conn.: Yale University Press, 2011. 